$\begin{array}{ll}\text { Türkiye Tarımsal Araştırmalar Dergisi } & \begin{array}{l}\text { Turk J Agric Res } \\ \text { http://dergi.sirt.edu.tr }\end{array} \\ \text { (2015) 2: 8-14 } \\ \text { TÜTAD } \\ \text { ISSN: 2148-2306 }\end{array}$

\title{
İmidacloprid ve Lambda-cyhalothrin'in Capoeta capoeta umbla Böbrek Dokusunda Glikoz 6-Fosfat Dehidrogenaz Enzimi Üzerine In Vitro Etkileri
}

\author{
Mahinur KIRICI ${ }^{1}$, Muammer KIRICI ${ }^{2 *}$, Mesut IŞIK ${ }^{3}$, Muhammed ATAMANALP ${ }^{4}$ \\ ${ }^{1}$ Bingöl Üniversitesi, Fen-Edebiyat Fakültesi, Kimya Bölümü, Bingöl, TÜRKiYE \\ ${ }^{2}$ Bingöl Üniversitesi, Ziraat Fakültesi, Su Ürünleri Bölümü, Bingöl, TÜRKIYE \\ ${ }^{3}$ Atatürk Üniversitesi, Fen Fakültesi, Kimya Bölümü, Erzurum, TÜRKIYE \\ ${ }^{4}$ Atatürk Üniversitesi, Su Ürünleri Fakültesi, Su Ürünleri Yetiştiriciliği Bölümü, Erzurum, TÜRKIYE
}

Geliş Tarihi/Received: 31.12 .2014

Kabul Tarihi/Accepted: 19.02 .2015

*Sorumlu Yazar/Correspondence: mkirici@bingol.edu.tr

Özet: Pestisit toksisitesi, metabolizmada DNA hasarı, lipid peroksidasyonunun artması, protein sulfidril gruplarının oksidasyonu ve enzim inaktivasyonu gibi oksidatif hasara neden olur. Bu çalışmada, Capoeta capoeta umbla (C. c. umbla) böbrek dokusundan imidacloprid ve lambda-cyhalothrin pestisitlerinin glikoz 6-fosfat dehidrogenaz (E.C.1.1.49; G6PD) enzimi üzerine etkileri in vitro olarak incelenmesi amaçlanmıștır. Bu amaç doğrultusunda enzim, C. c. umbla balık böbreğinden hemolizat hazırlanması, amonyum sülfat çöktürmesi ve 2',5'-ADP Sepharose 4B afinite kromatografisi yöntemleri kullanılarak spesifik aktivitesi $11.26 \mathrm{EÜ} \mathrm{mg}^{-1}$ protein ve $\% 22.7$ verimle saflaştırıldı. Enzim saflığını kontrol etmek için sodyum dodesil sülfat-poliakrilamid jel elektroforezi (SDS-PAGE) yapıldı ve enzimin tek bant olduğu görüldü. Çalışma sonucunda imidacloprid ve lambda-cyhalothrin pestisitlerinin in vitro olarak G6PD enzimini etkili bir şekilde inhibe ettiği belirlenmiştir. Sonuç olarak, lambda-cyhalothrin enzimi imidacloprid'den daha fazla inhibe etmektedir.

Anahtar Kelimeler: Capoeta capoeta umbla, glikoz 6-fosfat dehidrogenaz, saflaştırma, pestisit, inhibisyon

\section{In Vitro Effects of Imidacloprid and Lambda-cyhalothrin on Capoeta capoeta umbla Kidney Glucose 6-Phosphate Dehydrogenase Enzyme}

\begin{abstract}
Pesticide toxicity causes oxidative damage such as DNA damage, enhanced lipid peroxidation, the oxidation of protein sulfydryl groups and enzyme inactivation in the metabolism. In this study, we investigated the in vitro effects on glucose 6-phosphate dehydrogenase (E.C.1.1.49; G6PD) from Capoeta capoeta umbla kidney of imidacloprid and lambdacyhalothrin. For this purpose, the enzymewas purified from kidney of C. c. umbla with a specific activity of $11.26 \mathrm{EU} \mathrm{mg}^{-1}$ proteins and $22.7 \%$ yield using hemolysate preparation, ammonium sulfate precipitation and 2',5'-ADP Sepharose 4B affinity gel chromatography methods. In order to control the enzyme purification sodium dodecyl sulfate polyacrylamide gel electrophoresis (SDS-PAGE) was done. SDS-PAGE showed a single band for the enzyme. The results of this study suggested that imidacloprid and lambda-cyhalothrin have significant inhibition effect on the activity of G6PD in in vitro. In conclusion, lambda-cyhalothrin inhibits the enzyme activity more than imidacloprid.
\end{abstract}

Keywords: Capoeta capoeta umbla, glucose 6-phosphate dehydrogenase, purification, pesticide, inhibition

\section{Giriş}

Glukoz 6-fosfat dehidrogenaz (E.C.1.1.49; G6PD), pentoz fosfat yolunun başlangıç aşamasını katalizleyen önemli bir antioksidan enzimdir. G6PD enzimi, nikotinamid adenin dinükleotid fosfat (okside form; NADP ${ }^{+}$) varlığında glukoz 6fosfatın, 6-fosfoglukonata dönüşümünü sağlayarak 
hücre için hayati öneme sahip olan nikotinamid adenin dinükleotid fosfatın (redükte form; NADPH) oluşmasını sağlar (Lehninger ve ark., 1993; Keha ve Küfrevioğlu, 2004). NADPH'ın en önemli rolü ise okside glutatyonun (GSSG) indirgenmiş glutatyona (GSH) dönüşmesini sağlamaktır (Çiftçi ve ark., 2004).

İnsan nüfusunun hızla artışı beraberinde ihtiyaç duyulan besin gereksiniminin de artmasina neden olmuştur. Üreticiler, hem daha fazla para kazanmak, hem de daha kısa sürede insanların besin ihtiyacını karşılayabilmek için çeşitli yollarla sentezlenen hormon ve ilaçları kullanmaktadırlar. $\mathrm{Bu}$ ilaçlara genel olarak pestisit denmektedir. Pestisitler, ekonomik olmaları ve kullanımı kolay olduğu için üreticiler tarafından oldukça fazla kullanılmaktadır (Hopa, 2010).

Pestisitlerin üretimindeki amaç, hedef organizmadaki toksisitenin çok fazla, insandaki toksisitenin çok az olmasıdır. Fakat bilinçsizce ve aşırı kullanımı durumunda, toprağı ve suyu kirletmeleri yanında kullanıldıkları yerlerden fiziksel ve biyolojik yollarla çok uzak bölgelere taşınmaktadırlar (Bayar, 2013). Pestisitler, sucul ortamlarda yaşayan ve üreyen canlılara veya bitkilere karşı yapılan ilaçlamalarla, pestisit üretilen fabrikaların atıkları ile ve tarım bölgelerinde yapılan zirai faaliyetler sonucunda direkt veya yağmur suları ile su kaynaklarına karıșırlar (Atamanalp ve Yanık, 2001).

Tarımda yaygın olarak kullanılan ve sucul ortama girerek balıklar için büyük bir tehdit oluşturan pestisitler, oksidatif reaksiyonları katalizleyerek; hidrojen peroksit, süperoksit, singlet oksijen ve hidroksil radikali gibi reaktif oksijen türlerinin oluşumuna yol açarlar. $\mathrm{Bu}$ radikaller, oldukça yüksek reaktif bileşikler olup deoksiribo nükleik asit (DNA), protein ve lipid gibi önemli biyolojik moleküllerin oksidasyonuna ve işlevlerinin bozulmasına neden olur (Yu, 1994; Castillo ve ark., 2002). Reaktif oksijen türlerinin zararlı etkileri antioksidan savunma sistemleri tarafından nötralize edilmektedir. Sağlıklı bir hücrede metabolik tepkimeler sonucu oluşan reaktif radikaller ile çeşitli savunma mekanizmaları ile oluşturulan antioksidan molekül düzeyi arasında fizyolojik bir denge söz konusudur (Finkel ve Holdbrook, 2000; Smith ve ark., 2007). $\mathrm{Bu}$ dengenin oksidanlar yönünde bozulması oksidatif stres olarak tanımlanır (Sies, 1997). Bu durum ise hücre işlevlerinin bozulması, apoptoz veya nekrozla sonuçlanabilir. Dolayısıyla, antioksidan savunma sistemlerinin işlevselliği ve oksidanlar/antioksidanlar dengesinin sağlanması hücre için yaşamsal öneme sahiptir (Nordberg ve Arner, 2001).
$\mathrm{Bu}$ çalışmamızda ülkemiz içsularında yoğun şekilde bulunan, avlanarak insanlar tarafindan tüketilen ve ekonomik değeri olan C. c. umbla böbrek dokusundan, önemli bir antioksidan enzim olan G6PD enziminin saflaştırılması amaçlanmıştır. Ayrıca, saflaştırma işlemlerinin ardından tarımsal faaliyetlerde sıklıkla kullanılan imidacloprid ve lambda-cyhalothrin pestisitlerinin enzimler üzerine inhibisyon etkileri incelenmiştir.

\section{Materyal ve Yöntem}

\subsection{Balık materyali}

Araştırmada, iç sularımızda bulunan ve kaliteli gıda kaynağı olarak insanlar tarafindan özellikle İç Anadolu, Doğu Anadolu ve Güneydoğu Anadolu Bölgesi'nde fazlaca tüketilen C. c. umbla balıkları kullanılmıştır. Balık materyali örnekleri, Bingöl ili Genç ilçesinden geçen Murat Nehrinde tek istasyonda yakalanmıştır.

\subsection{Homojenatın hazırlanması}

Ortalama ağırlıkları yaklaşık 200 g olan 10 adet balık soğuk zincir kuralına göre laboratuvara getirilerek böbrek dokuları hızlı bir şekilde çıkarılmış ve bir kompozit oluşturulmuştur. Çalışmaya 24 saat içinde başlanmış ve dokular çalışmaya başlanacağı süreye kadar $-20{ }^{\circ} \mathrm{C}$ 'de muhafaza edilmiștir. Hazırlanan kompozitten $10 \mathrm{~g}$ alınarak kan ve diğer kirlilikleri elimine etmek için \% 0.9'luk $\mathrm{NaCl}$ ile 3 defa yıkanmıştır. Doku homojenatlarını hazırlamak için, ilk olarak dokular ultraturrax homojenizatör cihazı kullanılarak parçalanmıştır. Daha sonra sıvı azot içinde parçalanarak toz haline getirilmiş ve $3 \mathrm{ml} \mathrm{g}^{-1}$ olacak şekilde $50 \quad \mathrm{mM} \quad \mathrm{KH}_{2} \mathrm{PO}_{4} \quad(\mathrm{pH}=7.4)$ homojenat tampon çözeltisinin içinde homojenize edilmiştir. $\mathrm{Bu}$ süspansiyon 60 dakika 13000 rpm'de 2 defa santrifüj edilmiştir. Pelet atılarak, süpernatant daha sonraki saflaştırma basamaklarında kullanılmıştır (Çam, 2011).

\subsection{Enzim aktivitesinin ölçümü}

G6PD enziminin aktivitesi $25{ }^{\circ} \mathrm{C}$ 'de Beutler metoduna göre $340 \mathrm{~nm}$ 'de spektrofotometrede ölçülerek belirlenmiştir (Beutler, 1971).

\subsection{Amonyum sülfat çöktürmesi ve diyaliz}

C. c. umbla böbrek dokusundan elde edilen G6PD enzim homojenatı sirasiyla \% 0-20, \% 20 $30, \% 30-40, \% 40-50, \% 50-60, \% 60-70$ ve $\% 70$ 80 aralıklarında katı amonyum sülfat ile çöktürülmüştür. Çöktürme işlemleri sırasında 13000 rpm'de 15 dakika boyunca santrifüj yapılmıştır. Her defasında çökelekte ve süpernatant da enzim aktivitesine bakılmıştır. Amonyum sülfat çöktürmesi sırasında homojenata katı amonyum 
sülfat yavaş yavaş katılmış ve her defasında daha önce katılan amonyum sülfatın çözünmüş olmasına dikkat edilmiştir. Amonyum sülfatın homojenatta çözünme işlemi buz banyosunda manyetik karıştırıcı ile yapılmıştır. İşlem sonucunda, $C$. $c$. umbla böbrek G6PD enziminin amonyum sülfat çöktürme aralığ 1 \% 40-80 olarak belirlenmiştir.

Önce \% 40 doygunlukta amonyum sülfat çöktürmesi yapılmıştır. Numune santrifüj tüplerine konularak 13000 rpm'de 15 dakika santrifüj yapılarak çökelek kısmı atılmış, süpernatant kısmı alınmıştır. Daha sonra elde edilen homojenatta \% 80 doygunlukta amonyum sülfat çöktürmesi gerçekleştirilmiştir. Elde edilen numune 13000 rpm'de 15 dakika santrifüj edilmiştir. Süpernatant kısmı atılmış, çökelek çözünebileceği minimum fosfat tamponunda (50 mM KH $\mathrm{KH}_{2} \mathrm{PO}_{4}, \mathrm{pH}$ 7.4) çözülmüş̧ür. Amonyum sülfat çöktürmesi işlemleri sırasında ortamın sıcaklığı buz banyosuyla düşük tutulmaya çalışılmıştır. Amonyum sülfat çöktürmesi sonucu elde edilen numune diyaliz torbasına yerleştirilerek bir saat süreyle diyaliz tamponuna $\left(50 \mathrm{mM} \mathrm{KCH}_{3} \mathrm{COO}+\right.$ $50 \mathrm{mM} \mathrm{KH}{ }_{2} \mathrm{PO}_{4}, \mathrm{pH}$ 7.5) karşı diyaliz edilmiştir (Morelli ve ark., 1978; Ninfali ve ark., 1990). Çalışmada enzimin kullanıldığı bütün aşamalar 4 ${ }^{\circ} \mathrm{C}$ 'de gerçekleştirilmiştir.

\subsection{Afinite kolonunun hazırlanması}

10 ml'lik yatak hacmi için $2 \mathrm{~g}$ kuru 2',5'-ADP Sepharose 4B jeli tartılarak, $400 \mathrm{ml}$ destile su ile katı maddelerin uzaklaştırılması için birkaç defa yıkanmıştır. Yıkama esnasında jel şişirilmiştir. Şişirilmiş jelin havası su trombu kullanılarak, vakum ile alındiktan sonra dengeleme tamponu $\left(0.1 \mathrm{M} \mathrm{KCH} \mathrm{KCOO}_{3} \mathrm{CO} \mathrm{M} \mathrm{KH}_{2} \mathrm{PO}_{4}, \mathrm{pH}=6.0\right)$ ilave edilerek jel süspanse edilmiştir. Süspanse edilmiş jel, 1x10 cm'lik kapalı sistemden oluşan soğutmalı kolona paketlenmiştir. Jel çöktükten sonra peristaltik pompa yardımıyla dengeleme tamponu ile yıkanmıştır. Dengelemede ve yıkamada akış hızı $50 \quad \mathrm{ml} \mathrm{h}^{-1}$ absorbansının eşitlenmesinden anlaşılmıştır. Böylece afinite kolonu hazırlanmıştır (Çam, 2011).

\subsection{Numunenin afinite kolonuna tatbiki ve G6PD'nin elüsyonu}

Amonyum sülfat çöktürmesinden elde edilen derişikleştirilmiş numune, $0.1 \mathrm{M} \mathrm{KCH}_{3} \mathrm{COO}+0.1$ $\mathrm{M} \mathrm{KH}{ }_{2} \mathrm{PO}_{4}(\mathrm{pH}=6.0)$ tamponu ile dengelenmiş kolona tatbik edilmiştir. Daha sonra kolon sırasıyla $25 \mathrm{ml} 0.1 \mathrm{M} \mathrm{KCH}_{3} \mathrm{COO}+0.1 \mathrm{M} \mathrm{KH}_{2} \mathrm{PO}_{4}(\mathrm{pH}=$ 6.0), $25 \mathrm{ml} 0.1 \mathrm{M} \mathrm{KCH}{ }_{3} \mathrm{COO}+0.1 \mathrm{M} \mathrm{KH}_{2} \mathrm{PO}_{4}$ $(\mathrm{pH}=7.85)$ ve $25 \mathrm{ml} 0.1 \mathrm{M} \mathrm{KCl}+0.1 \mathrm{M} \mathrm{KH}_{2} \mathrm{PO}_{4}$ $(\mathrm{pH}=7.85)$ çözeltisiyle yıkanmıştır. Dengeleme ve yıkama hızı $50 \mathrm{ml} \mathrm{h}^{-1}$ 'e ayarlanmıştır. Akış hızı perilstaltik pompa ile kontrol altında tutulmuştur.
Böylece enzimin büyük bir kısmı jele tutunmuş ve diğer safsızlıklar uzaklaştırılmıştır. Daha sonra 80 $\mathrm{mM} \mathrm{KH} \mathrm{KO}_{4}+80 \mathrm{mM} \mathrm{KCl}+0.5 \mathrm{mM} \mathrm{NADP}^{+}+$ $10 \mathrm{mM}$ EDTA $(\mathrm{pH}=7.85)$ çözeltisi kolona uygulanarak enzim elüe edilmiştir. Elüsyonlar $1 \mathrm{ml}$ olacak şekilde ependorf tüplere alınmış ve her birinde aktivite ayrı ayrı ölçülmüştür. Bütün bu işlemler esnasında sıcaklık $4{ }^{\circ} \mathrm{C}$ 'de kontrol altında tutulmuştur (Morelli ve ark., 1978; Ninfali ve ark., 1990).

\subsection{Sodyum dodesil sülfat-poliakrilamid jel elektroforezi (SDS-PAGE)}

Enzim saflaştırıldıktan sonra enzimin saflık derecesi, \% 3-8 kesikli SDS-PAGE kullanılarak Laemmli metoduna göre belirlenmiştir (Şekil 1) (Laemmli, 1970).

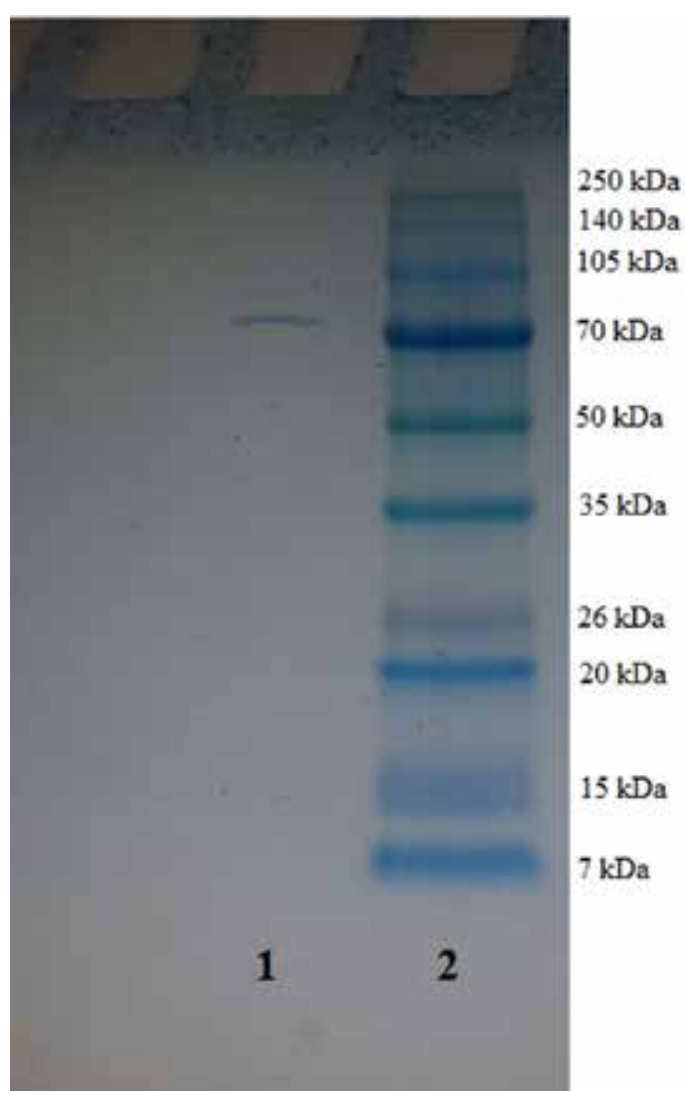

Şekil 1. C. c. umbla böbrek dokusundan saflaştırılan G6PD enziminin SDS-PAGE bandları (1: Böbrek; 2: Standart Proteinler)

\subsection{Protein miktarının hesaplanması}

Protein miktarının ölçümü Bradford metoduna göre 595 nm'de spektrofotometre kullanılarak yapılmıştır. Ölçümde sı̆̆ır serum albumin (BSA) proteini standart olarak kullanılmıştır (Bradford, 1976). 


\subsection{In vitro olarak pestisitlerin etkisi}

İnhibitör olarak imidacloprid ve lambdacyhalothrin pestisitleri kullanılmıştır. İnhibitör uygulanan ve inhibitör uygulanmayan çalışmalarda substrat (G6-P) konsantrasyonlar1, 0.03, 0.06, 0.09, 0.15 ve $0.27 \mathrm{mM}$ olarak uyguland. İnhibitör konsantrasyonu $\left(\mathrm{IC}_{50}\right)$ değerini hesaplamak için beş farklı inhibitör konsantrasyonu belirlenmiştir (imidacloprid: $2.33,2.72,3.27,3.5$ ve $3.89 \mathrm{mM}$; lambda-cyhalothrin: $0.1,0.4,0.53,0.7$ ve 0.8 $\mathrm{mM})$. Her bir pestisit için 5 farklı inhibitör konsantrasyonlarında yüzde (\%) Aktivite-[Pestisit] grafikleri çizildi. Pestisit uygulanmayan küvetin aktivitesi \% 100 kabul edilmiş, \% 50 inhibisyona neden olan pestisit konsantrasyonu $\left(\mathrm{IC}_{50}\right)$ grafiklerinden hesaplanmıştır (Çam, 2011).

$\mathrm{IC}_{50}$ değerleri hesaplanan imidacloprid ve lambda-cyhalothrin pestisitlerinin $\mathrm{K}_{\mathrm{i}}$ değerlerini belirlemek amaciyla C. c. umbla böbrek G6PD enzim aktivitesini yarıya düşüren pestisit konsantrasyonu ile bu değerin altında ve üstünde iki sabit pestisit konsantrasyonları alınarak, uygun beş substrat konsantrasyonu ile aktivite ölçümleri yapılmıştır. Çalışmalarda uygun beş farklı substrat konsantrasyonu stok çözelti kullanılarak ön deneme ile belirlenmiştir. Elde edilen değerlerle her bir inhibitör için Lineweaver-Burk grafikleri çizilmiştir. Grafik denkleminde yarışmalı inhibisyon için eğime eşit olan Eşitlik 1 ifadesinden, yarışmasız inhibisyon için Eşitlik 2'den yararlanılarak $K_{i}$ değerleri belirlenmiştir (Çam, 2011).

$$
\begin{gathered}
K_{M} / V_{\max }\left(1+[I] / K_{i}\right) \\
V_{\max }=V_{\max }^{I}\left(1+[I] / K_{i}\right)
\end{gathered}
$$

$\mathrm{Bu}$ eşitliklerde; $K_{M}$, Michaelis-Menten sabiti; $V_{\max }$, Maksimum hı; $I$, İnhibitör; $K_{i}$, Enzim inhibitör kompleksinin ayrışma sabiti; $V_{\max }^{I}$, İnhibitörün maksimum hızını ifade etmektedir.

\section{Bulgular ve Tartışma}

Bu çalışmada, iç sularımızda bulunan C. c. umbla balığının böbrek dokusundan G6PD enzimi saflaştırılarak, imidacloprid ve lambda-cyhalothrin pestisitlerinin G6PD enzimi üzerine etkileri in vitro olarak incelenmiştir.

Çalışmanın ilk basamağında C. c. umbla böbrek dokusundan homojenat hazırlanmış ve elde edilen homojenattan amonyum sülfat çöktürmesi yapılarak G6PD enziminin \% 40-80 amonyum sülfat doygunluk aralığında daha yoğun şekilde çöktüğü belirlenmiştir. Başka canlı ve dokularda G6PD enziminin amonyum sülfat doygunluk aralığını belirlemek için birçok çalışma yapılmıştır. Örneğin; gökkuşağı alabalığı eritrositinde \% 40-65 (Erdoğan ve ark., 2005), çipura karaciğerinde \% 40-60 ve solungacında \% 50-70 (Çam, 2011), insan eritrositlerinde \% 35-65 (Büyükokuroğlu ve ark., 2001), Bacillus sp. bakterisinde \% 0-60 (Çiftçi ve ark., 2004), kaz eritrositinde \% 40-60 (Beydemir ve ark., 2003), koyun eritrositinde \% 50-60 ve göz lensinde \% 0-30 (Beydemir, 2002) amonyum sülfat doygunluk aralıkları belirlenmiştir. Amonyum sülfat çöktürmesi uzun zamandan beri uygulanan kısmi bir saflaştırma yöntemidir. Amonyum sülfat çöktürmesi yöntemi kullanılarak bazı safsızlıklar uzaklaştırılır ve böylece proteinler biraz daha saf olarak elde edilir. Amonyum sülfat çöktürmesinden sonra numuneye diyaliz yapılarak ortamdaki diğer iyonların ortamdan uzaklaştırılması sağlanır (Çiftçi ve ark., 2004).

Saflaştırma işlemi sonunda Tablo 1'de görüldüğü gibi spesifik aktivitesi $11.26 \mathrm{EÜ} \mathrm{mg} \mathrm{mg}^{-1}$ protein olan enzim, \% 22.7 verimle 402.14 kat saflaştırılmıştır. Enzimlerin saflığını kontrol etmek için SDS-PAGE yapılmış ve jelde tek band gözlenmiştir (Şekil 1). Şentürk ve ark. (2009) gökkuşağ1 alabalığı eritrositlerinde G6PD enzimini, \% 63 verimle 1691 kat ve spesifik aktivite $16.235 \mathrm{EÜ} \quad \mathrm{mg}^{-1}$ protein olarak

Tablo 1. C. c. umbla böbrek G6PD enziminin 2',5'- ADP Sepharose-4B afinite kolon materyali ile saflaştırılma

\begin{tabular}{|c|c|c|c|c|c|c|c|c|}
\hline Numune türü & $\begin{array}{l}\text { Aktivite } \\
\left(\mathrm{EÜ} \mathrm{ml}^{-1}\right)\end{array}$ & $\begin{array}{l}\text { Protein } \\
\left(\mathrm{mg} \mathrm{ml}^{-1}\right)\end{array}$ & $\begin{array}{l}\text { Toplam } \\
\text { hacim } \\
(\mathrm{ml})\end{array}$ & $\begin{array}{l}\text { Toplam } \\
\text { aktivite } \\
\text { (EÜ) }\end{array}$ & $\begin{array}{l}\text { Toplam } \\
\text { protein } \\
(\mathrm{mg})\end{array}$ & 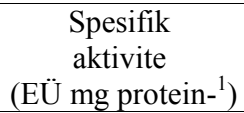 & $\begin{array}{c}\text { Saflaştırma } \\
\text { katsayısı }\end{array}$ & $\begin{array}{c}\% \\
\text { Verim }\end{array}$ \\
\hline Homojenat & 0.274 & 9.78 & 31 & 8.494 & 303.18 & 0.028 & 1 & 100.0 \\
\hline $\begin{array}{l}\text { Amonyum } \\
\text { sülfat } \\
\text { çöktürmesi ve } \\
\text { diyaliz }\end{array}$ & 0.462 & 14.2 & 6 & 2.772 & 85.2 & 0.033 & 1.18 & 32.6 \\
\hline $\begin{array}{l}\text { 2',5'- ADP } \\
\text { Sepharose-4B } \\
\text { afinite kromatografisi }\end{array}$ & 0.642 & 0.057 & 3 & 1.926 & 0.171 & 11.26 & 402.14 & 22.7 \\
\hline
\end{tabular}
basamakları 
saflaştırmıştır. Çam (2011) çipura balıklarının karaciğer ve solungaç dokularından G6PD enzimini saflaştırmış, çalışma sonucunda, G6PD enzimi çipura karaciğer dokusundan spesifik

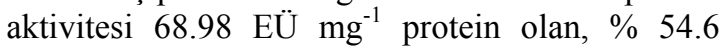
verimle ve yaklaşık 1864.3 kat; solungaç dokusundan, spesifik aktivitesi $17.15 \mathrm{EÜ} \mathrm{\textrm {mg } ^ { - 1 }}$ protein olan, \% 52.2 verimle ve yaklaşı $283 \mathrm{~kat}$ saflaştırılmıştır. Hu ve ark. (2013), Ot Sazanı (Ctenopharyngodon idella) hepatopankreasindan G6PD enzimini \% 19.5 verimlilikle, 1.066 kat ve spesifik aktivite $18 \mathrm{EÜ} \mathrm{mg}^{-1}$ protein olarak saflaştırmıştır.

İmidacloprid ve lambda-cyhalothrin pestisitlerinin in vitro şartlarda saflaştırılan enzimi inhibe ettikleri belirlenmiştir. İnhibisyon etkisi gösteren bu pestisitlerin $\mathrm{IC}_{50}$ değerleri imidacloprid için $2.83 \mathrm{mM}$ ve lambda-cyhalothrin için $0.565 \mathrm{mM}$ olarak hesaplanmıştır. İnhibisyon tipini belirlemek için Lineweaver-Burk grafikleri çizilmiş ve elde edilen grafikten $K_{i}$ sabitleri imidacloprid için $0.931 \pm 0.052$ ve lambdacyhalothrin için $0.666 \pm 0.022 \mathrm{mM}$ olarak tespit edilmiştir (Tablo 2 ve Şekil 2). Araştırma sonucunda, lambda-cyhalothrin'in imidacloprid'den daha fazla inhibe ettiği tespit edilmiştir.
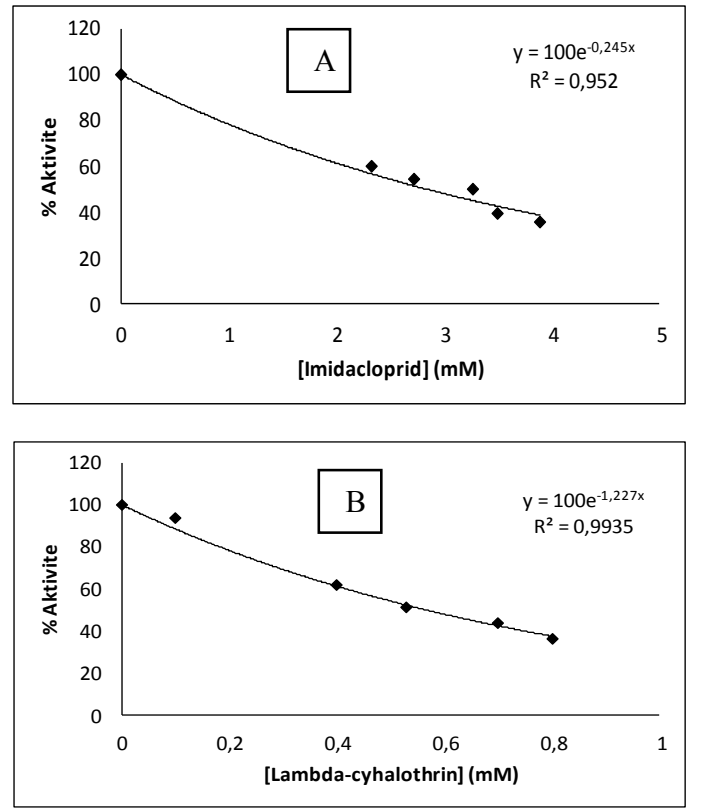

Tablo 2. C. c. umbla böbrek G6PD enzimi için \% Aktivite-[I] ve Lineweaver-Burk grafiklerinden elde edilen $\mathrm{IC}_{50}$ değerleri, $K_{i}$ sabitleri ve inhibisyon tipleri

\begin{tabular}{lccc}
\hline Pestisitler & $\mathrm{IC}_{50}(\mathrm{mM})$ & $\mathrm{K}_{\mathrm{i}}(\mathrm{mM})$ & $\begin{array}{c}\text { İnhibisyon } \\
\text { tipi }\end{array}$ \\
\hline $\begin{array}{l}\text { İmidacloprid } \\
\text { Lambda- } \\
\text { cyhalothrin }\end{array}$ & 2.83 & $0.931 \pm 0.052$ & Yarışmasıs \\
\hline
\end{tabular}

Gökkuşağı alabalığı (Oncorhynchus mykiss) ve sazan (Cyprinus carpio carpio) balıklarında yapılan bir çalışmada; lambda-cyhalothrin, deltametrin, diozinon, dorzolamide ve brinzolamide pestisitlerinin balık kanı karbonik anhidraz (CA) enzimini inhibe ettikleri bildirilmiştir (Doğan, 2006). Şentürk ve ark. (2009) in vivo ve in vitro olarak bazı pestisitlerin (deltamethrin, cypermethrin ve propoxur) gökkuşağı alabalığı eritrositinde G6PD enzimine etkisini incelemiş̧lerdir. Araştırma sonuçlarına göre; in vitro çalışmada, deltamethrin, cypermethrin ve propoxur enzimi inhibe ettiği belirlenmiştir. Aynı araştırmada, $\mathrm{IC}_{50}$ değerleri deltamethrin için $0.63 \mathrm{mM}$, cypermethrin için 1.02 $\mathrm{mM}$ ve propoxur için $12 \mathrm{mM}$ olarak hesaplamışlardır. In vivo çalışmada sadece
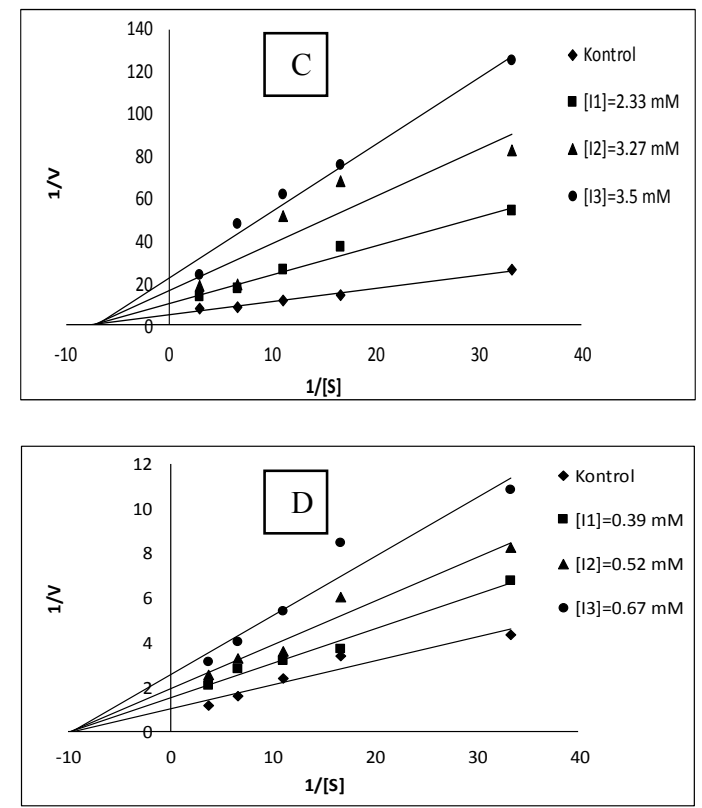

Şekil 2. A, B: C.c. umbla böbrek G6PD enzimi için 5 farklı imidacloprid ve lambda-cyhalothrin konsantrasyonunda elde edilen \% Aktivite-[Pestisit] grafiği. C, D: C. c. umbla böbrek G6PD enzimi için 3 sabit imidacloprid ve lambda-cyhalothrin için 5 farklı substrat konsantrasyonlarında çizilen Lineweaver-Burk grafiği 
deltamethrinin enzimi inhibe ettiğini bildirmişlerdir. Yine gökkuşağı alabalığı kullanılarak yapılan bir çalışmada (Ceyhun ve ark., 2010); in vivo ve in vitro olarak deltamethrin, diazinon, cypermethrin ve propoxur pestisitlerinin balık solungaç CA enzimine etkileri incelenmiş ve in vivo çalışmada sadece deltamethrinin önemli bir inhibisyon etkisi gösterdiği belirlenmiştir. Bununla beraber in vitro çalışmada deltamethrin, diazinon, propoxur ve cypermethrin CA enzimini inhibe ettiği ve sırasıyla $\mathrm{IC}_{50}$ değerleri $0.137,0.267,0.420$ ve $0.460 \mu \mathrm{M}$ olarak tespit edildiği bildirilmektedir.

$\mathrm{Bu}$ araştırma sonucunda; birçok çalışmalara paralel olarak, kullanilan pestisitler balık dokusunda incelenen G6PD enzimini inhibe ederek balığa zarar verdiği belirlenmiștir.

\section{Sonuç ve Öneriler}

Çalışma sonucunda Capoeta capoeta umbla böbrek dokusundan G6PD enzimi, spesifik aktivite $11.26 \mathrm{EÜ} \mathrm{mg}^{-1}$ protein ve \% 22.7 verimle 402.14 kat saflaştırılmıştır. Bununla beraber, in vitro olarak imidacloprid ve lambda-cyhalothrin pestisitlerinin G6PD enzimini inhibe ettikleri belirlenmiştir.

Yoğun ve bilinçsiz pestisit kullanımı sonucunda, ekolojik sistem tahrip olmaktadır. Pestisit kaynaklı olumsuz çevresel etkileri azaltmak için;

Pestisit uygulamaları, bilimsel verilere dayalı olarak yapılmalı; üreticiler eğitilmeli; geniș spektrumlu olmayan, toprak ve suda çabuk parçalanan, ekolojik dengenin devamını sağlayan, kirlilik yaratmayan pestisitlerin kullanımı tercih edilmeli; uzun vadede pestisit kullanımı azaltılmalı ve organik tarım veya biyolojik tarım gibi alternatif mücadele yöntemleri kullanılmalıdır.

\section{Kaynaklar}

Atamanalp, M., Yanık, T., 2001. Pestisitlerin Cyprinidae'lere toksik etkileri. Ege Üniversitesi Su Ürünleri Dergisi, 18(3-4): 555-563.

Bayar, A.S., 2013. Tatlı su balığ1 Oreochromis niloticus'un gonad histolojisi üzerindeki piretroid pestisit deltamethrinin etkileri ve E vitaminin etkisi. Yüksek lisans tezi, Dicle Üniversitesi Fen Bilimleri Enstitüsü, Diyarbakır.

Beutler, E., 1971. Red Cell Metabolism Manual of Biochemical Methods. Academic Press, London.

Beydemir, S., Yılmaz, H., Çiftçi, M., Küfrevioğlu, Ö.İ., 2003. Purification of glucose 6-phosphate dehydrogenase from goose erythrocytes and kinetic properties. Turkish Journal of Veterinary and Animal Sciences, 27: 1179-1185.

Beydemir, Ş., 2002. Koyun eritrositleri ve göz lensinden glukoz-6-fosfat dehidrogenaz enziminin saflaştırılması, karakterizasyonu, bazı ilaç ve kimyasal maddelerin inhibisyon veya aktivasyon kinetiklerinin incelenmesi. Doktora tezi, Atatürk Üniversitesi Fen Bilimleri Enstitüsü, Erzurum.

Bradford, M.M., 1976. A rapid and sensitive method for the quantization of microgram quantities of protein utilizing the principle of protein-dye binding. Analytical Biochemistry, 72: 248-251.

Büyükokuroğlu, M.E., Altıkat, S., Çiftçi, M., Banoğlu, Z.N., Göçer, F., 2001. Klorpromazin ve haloperidol'ün insan eritrosit glukoz 6-fosfat dehidrogenaz enzimi üzerine in vitro etkileri. Klinik Psikofarmokoloji Bülteni, 11: 101-105.

Castillo, C.G., Montante, M., Dufour, L., Martinez, M.L., Jimenez-Capdeville, M.E., 2002. Behavioral effects of exposure to endosulfan and methyl parathion in adult rats. Neurotoxicology and Teratology, 24: 797-804.

Ceyhun, S.B., Şentürk, M., Erdoğan, O., Küfrevioğlu, Ö.İ., 2010. In vitro and in vivo effects of some pesticides on carbonic anhydrase enzyme from rainbow trout (Oncorhynchus mykiss) gills. Pesticide Biochemistry and Physiology, 97: 177-181.

Çam, M., 2011. Glukoz 6-fosfat dehidrogenaz enziminin çipura karaciğer ve solungaç dokularından saflaştırılması ve enzim aktivitesi üzerine bazı metallerin etkilerinin incelenmesi. Yüksek lisans tezi, Atatürk Üniversitesi Fen Bilimleri Enstitüsü, Erzurum.

Çiftçi, M., Adıgüzel, A., Erat, M., Şahin, F., 2004. Bacillus sp. (BA-142) bakterisinden glukoz 6-fosfat dehidrogenaz enziminin kısmen saflaştırılması ve bazı kinetik özelliklerinin belirlenmesi. Atatürk Üniversitesi Ziraat Fakültesi Dergisi, 35(3-4): 151158.

Doğan, S., 2006. The in vitro effects of some pesticides on carbonic anhydrase activity of Oncorhynchus mykiss and Cyprinus carpio carpio fish. Journal of Hazardous Materials A, 132: 171-176.

Erdoğan, O., Hisar, O., Köroğlu, G., Çiftçi, M., 2005. Sublethal ammonia and urea concentrations inhibit rainbow trout (Oncorhynchus mykiss) erythrocyte glucose 6-phosphate dehydrogenase. Comparative Biochemistry and Physiology Part C, 141: 145-150.

Finkel, T., Holbrook, N.J., 2000. Oxidants, oxidative stress and the biology of ageing. Nature, 408(6809): 239-247.

Hopa, E., 2010. İnsan eritrositlerinden glukoz 6-fosfat dehidrogenaz enziminin saflaştırılması, bazı kumarin ve pestisitlerin etkilerinin araştırılması. Doktora tezi, Balıkesir Üniversitesi Fen Bilimleri Enstitüsü, Balıkesir.

Hu, W., Zhi, L., Zhuo, M., Zhu, Q., Zheng, J., Chen, Q., Gong, Y., Liu, C., 2013. Purification and characterization of glucose 6-phosphate dehydrogenase from grass carp (Ctenopharyngodon idella) and inhibition effects of several metal ions on G6PD activity in vitro. Fish Physiology and Biochemistry, 39: 637-647.

Keha, E., Küfrevioğlu, Ö.İ., 2004. Biyokimya. Aktif Yayınevi, Erzurum. 
Laemmli, U.K., 1970. Clevage of structural proteins during assembly of the head of bacteriophage T4. Nature, 227: 680-683.

Lehninger, A.L., Nelson, D.L., Cox, M.M., 1993. Principles of Biochemistry. Worth Publishers, New York.

Morelli, A., Benatti, U., Gaetani, G.F., De Flora, A., 1978. Biochemical mechanisms of glucose-6phosphate dehydrogenase deficiency. Proceedings of the National Academy of Sciences, 75: 1979-1983.

Ninfali, P., Orsenigo, T., Barociani, L., Rapa, S., 1990. Rapid purification of glucose-6 phosphate dehydrogenase from mammal's erythrocyte. Preparative Biochemistry, 20: 297-309.

Nordberg, J., Arner, E.S.J., 2001. Reactive oxygen species, antioxidants, and the mammalian thioredoxin system. Free Radical Biology and Medicine, 31(11): 1287-1312.

Sies, H., 1997. Oxidative stress: oxidants and antioxidants. Experimental Physiology, 82: 291-295.

Smith, C., Marks, A.D., Lieberman, M., 2007. Mark's Temel Tıbbi Biyokimyası, Klinik Yaklaşım. (Çeviri: İnal ME, Atik U, Aksoy N \& Haşimi A), Güneş Tıp Kitabevleri, Ankara.

Şentürk, M., Ceyhun, S.B., Erdoğan, O., Küfrevioğlu, Ö,I., 2009. In vitro and in vivo effects of some pesticides on glucose-6-phosphate dehydrogenase enzyme activity from rainbow trout (Oncorhynchus mykiss) erythrocytes. Pesticide Biochemistry and Physiology, 95: 95-99.

Yu, B.P., 1994. Cellular defenses aganist damage from reactive oxygen species. Physiological Reviews, 74(1): 39-16. 